Ethos : Jurnal Penelitian dan Pengabdian kepada Masyarakat, Vol 7, No.1, Januari 2019: 151-162

\title{
Pengaruh Pendidikan dan Pelatihan Terhadap Peningkatan Kompetensi SUPERVisi KePala SEKOlaH DASAR di KabUPATEN BANDUNG
}

\author{
Nursyamsinar Nursiti \\ Lembaga Penjaminan Mutu Pendidikan Jawa Barat \\ E-mail:nursiti_19@yahoo.com
}

\begin{abstract}
This research was based on reality that the supervision skills of headmasters in Bandung District is still under expectation. It was because that most headmasters do not understand the supervision procedures towards teachers' performances. Therefore, the purpose of this research is to evaluate the impact of training to headmaster candidates towards their supervision skills in level primary school in Bandung District. This study used quantitative approach with survey to gain the data from purposive sample (72 candidates) using questionnaire (Likert scale), documentation and test. Data analysis used was Product Moment correlation test with the result: (1) the training of primary school headmaster candidates held by LPMP Jawa Barat was in high level category which is effective and reached the target based on pre and post test which showed significant result; (2) after training, the supervision skill of the candidates was improved and support teachers in solving teaching problems in order to improve learning quality; (3) the training gave significant improvement. The recommendation based on this study are: (1) the training content should be more details and complete in order to gain candidates' comprehension; (2) the supervision instrument should be developed systematically; and (3) this study should be followed up to seek other factors and apply on different research subjects.
\end{abstract} Keywords: Training and Supervision Skills.

\begin{abstract}
Abstrak. Latarbelakang masalah kompetensi supervsi kepala sekolah di Kabupaten Bandung masih rendah, karena belum memahami prosedur melaksanakan supervisi. Tujuan penelitian ini untuk mengkaji seberapa besar pengaruh pendidikan dan pelatihan calon kepala sekolah terhadap peningkatan kompetensi supervisi kepala sekolah dasar Kabupaten Bandung. Metode penelitian digunakan metode survai dengan pendekatan kuantitatif. Sampel sama dengan populasi yaitu 72 orang. Instrumen pengumpulan data, meliputi angket, dokumentasi dan tes. Analisis data digunakan uji korelasi Product Moment. Kesimpulan (1) pendidikan dan pelatihan calon kepala sekolah dasar Kabupaten Bandung di LPMP Jawa Barat, secara keseluruhan berada pada kategori tinggi, dan efektif dapat mencapai target yang ditentukan, karena terdapat peningkatan nilai yang signifikan; (2) kompetensi supervisi kepala sekolah dasar Kabupaten Bandung setelah pendidikan dan pelatihan di LPMP Jawa Barat, secara keseluruhan berada pada kategori tinggi, karena dapat meningkatkan kualitas pembelajaran guru dan prestasi peserta didik; (3) pendidikan dan pelatihan calon kepala sekolah dapat memberikan pengaruh yang signifikan terhadap peningkatan kompetensi supervisi kepala sekolah dasar di Kabupaten Bandung (1) materi pendidikan dan pelatihan agar disusun lebih rinci, sistimatis, dan lengkap; (2) mengembangkan kisi-kisi instrumen supervisi akademik; dan (3) penelitian ini perlu ditindaklanjuti lebih komprehensif dengan subjek penelitian yang berbeda.
\end{abstract}

Kata Kunci : Pendidikan dan Pelatihan, Kompetensi Supervis 


\section{Pendahuluan}

Salah satu kompetensi yang harus dikuasai kepala sekolah berdasarkan Permendiknas Nomor 13 tahun 2007, adalah melakukan supervisi terhadap guru. Purwanto (2008:76) bahwa supervisi adalah suatu aktivitas pembinaan untuk membantu guru melaksanakan pembelajaran secara efektif. Oleh karena itu kompetensi supervisi kepala sekolah, mencakup (1) merencanakan program supervisi akademik; (2) melaksanakan supervisi akademik; dan (3) tindak lanjut hasil supervisi akademik (Depdiknas, 2008:228).

Pentingnya supervisi dilakukan (1) meningkatkan kualitas pembelajaran di kelas; (2) memadukan perbaikan pembelajaran menjadi lebih sempurna; (3) meningkatkan kualitas dan kemampuan guru (Satori,2004:29). Untuk mencapai hasil pembelajaran yang baik, diperlukan kemampuan kepala sekolah dalam melaksanakan supervisi akademik baik perencanaan, pelaksanaan, dan tindak lanjut, agar semua aktivitas berjalan secara terarah sesuai tujuan yang diharapkan.

Kenyataan di sekolah-sekolah menunjukkan masih banyak kepala sekolah perlu ditingkatkan kemampuan supervisi, karena belum memahami prosedur melaksanakan supervisi. Hal ini dapat dilihat dari hasil analisis kebutuhan pengembangan keprofesian yang dilakukan LPMP Jawa Barat bagi calon kepala sekolah yang lulus seleksi akademis, diperoleh nilai kompetensi kepribadian $(82 \%)$, manajerial $(72 \%)$, kewirausahaan (62\%), supervisi (48\%), dan kompetensi sosial (68\%) (LPMP
Jabar, 2016). Dari hasil kajian tersebut menunjukkan kompetensi kepala sekolah, nilai yang terendah adalah kompetensi supervisi.

Syawal Gultom, Ketua Badan Pengembangan Sumber Daya Manusia Pendidikan dan Penjaminan Mutu Pendidikan Kementerian Pendidikan dan Kebudayaan, di Jakarta mengungkapkan kompetensi dan kinerja kepala sekolah jenjang TK, SD, SMP, dan SMA/SMK masih rendah. Hal ini, disebabkan karena pengangkatan kepala sekolah tidak berdasarkan kompetensi dan profesionalisme. Hal ini didukung oleh Siswandari, Kepala Lembaga Pengembangan dan Pemberdayaan Kepala Sekolah, banyak kepala sekolah yang sudah dilatih hingga memenuhi standar nasional tidak dipilih.. (https://edukasi.kompas.com/read/2012 kepala.Sekolah.Masih.Rendah, tanggal 24 Juli 2012).

Demikian pula hasil survey John Pettit dalam The 4th International Conference on Best Practice for School Leadership Development, bahwa salah satu kabupaten/kota di Jawa Barat termasuk kabupaten Bandung, kompetensi supervisi kepala sekolah masih rendah. Penyebabnya adalah sebagian besar kepala sekolah kurang menguasai kompetensi untuk melakukan pembinaan kepada gurunya dalam proses pembelajaran, sehingga penilaian untuk peningkatan kualitas belajar mengajar tidak dapat dilakukan secara akurat.

(https://www.kompasiana.com/samsunis arman/wow-kompetensi-supervisi kepala-sekolah-rendah,tanggal 24 Jun 2015). Oleh karena itu kegiatan supervisi kepala sekolah di Kabupaten Bandung 
perlu dilakukan secara efektif, agar kelemahan dalam proses pembelajaran dapat segera teratasi.

Berdasarkan permasalahan kompetensi kepala sekolah, dan tuntutan Permendiknas No 13 tahun 2007 dan Permendikbud No 6 tahun 2018, maka guru yang diberi tugas untuk menjadi kepala sekolah, perlu diangkat melalui prosedur dan harus memiliki sertifikat untuk menjadi kepala sekolah. Untuk itu penataan sistem rekrutmen calon kepala sekolah perlu dilakukan secara sistematik, meliputi seleksi administrasi, seleksi substansi, dan pendidikan dan pelatihan, agar diperoleh calon kepala sekolah yang terstandar. Salah satu lembaga untuk menyelenggarakan pendidikan dan pelatihan calon kepala sekolah adalah Lembaga Penjaminan Mutu Pendidikan (LPMP). Oleh karena itu penyelenggaraan pendidikan dan pelatihan calon kepala sekolah, menggunakan petunjuk pelaksanaan (Juklak) dan petunjuk teknisk (Juknis) diklat yang telah disusun LPPKS, agar menghasilkan kompetensi calon kepala sekolah yang terstandar. Diklat calon kepala sekolah dalam penelitian ini difokuskan pada salah satu kompetensi kepala sekolah, yaitu kompetensi supervisi akademik.

Berdasarkan latar belakang tersebut, salah satu upaya untuk meningkatkan kompetensi supervisi kepala sekolah, adalah melalui pendidikan dan pelatihan calon kepala sekolah, secara khusus calon kepala sekolah dasar di Kabupaten Bandung. Oleh karena itu, masalah utama penelitian ini, adalah "Seberapa besar pengaruh pendidikan dan pelatihan calon kepala sekolah terhadap peningkatan kompetensi supervisi kepala sekolah dasar di Kabupaten Bandung”. Secara operasional, masalah utama dirumuskan dalam bentuk pertanyaan penelitian bagaimana efektivitas penyelenggaraan pendidikan dan pelatihan calon kepala sekolah dasar Kabupaten Bandung di LPMP Jawa Barat ?

Bagaimana kompetensi supervisi kepala sekolah dasar Kabupaten Bandung setelah pendidikan dan pelatihan di LPMP Jawa Barat?

Seberapa besar pengaruh pendidikan dan pelatihan calon kepala sekolah terhadap peningkatan kompetensi supervisi kepala sekolah dasar di Kabupaten Bandung ?

\section{Kajian Teori}

\section{A. Konsep Supervisi Akademik \\ Kepala Sekolah}

Payong (2011:17) menjelaskan bahwa kompetensi adalah kemampuan yang dimiliki seseorang, akibat dari pendidikan maupun pelatihan, atau pengalaman belajar informal tertentu yang diperoleh, sehingga menyebabkan seseorang dapat melaksanakan tugas tertentu dengan hasil yang memuaskan. Standar kompetensi kepala sekolah berdasarkan Permendiknas Nomor 13 tahun 2007: (1) Kompeteni Kepribadian;

(2) Kompetensi Manajerial;

Kompetensi Kewirausahaan; dan (4) Kompetensi Supervisi. Tujuan supervisi menurut Sergiovanni (1987:36), untuk :
a. membantu meningkatkan profesionalisme guru
b. memonitor kegiatan pembelajaran di sekolah.;



c. mendorong guru dalam melaksanakan proses pembelajaran.

Komponen supervisi akademik dalam penelitian ini difokuskan pada Permendiknas Nomor 13 tahun 2007, yaitu (a) merencanakan program supervisi akademik, (b) melaksanakan supervisi akademik; dan (c) menindaklanjuti dari hasil supervisi dalam peningkatan profesionalisme guru.

\section{B. Konsep Pendidikan dan Pelatihan}

Notoatmodjo (2003:28) bahwa pendidikan dan pelatihan, adalah untuk mengembangkan sumber daya manusia, terutama mengembangkan kemampuan intelektual dan kepribadian masyarakat. Hasibuan (2001:86) pendidikan dan pelatihan adalah pembinaan pengetahuan terhadap kelompok fakta, aturan dan metode dengan megutamakan kejujuran dan keterampilan. Dari pendapat tersebut dapat disimpulkan bahwa pendidikan dan pelatihan adalah proses pembinaan untuk meningkatkan, mengembangkan, dan membentuk pegawai dalam suatu instansi, agar dapat mempelajari pengetahuan, keterampilan, dan perilaku, sehingga tercipta sumber daya manusia yang berkualitas.

Tujuan pendidikan dan pelatihan menurut Sulistiyani \& Rosidah (2009:21) adalah (a) perencanaan melalui penilaian kebutuhan pelatihan; (b) pengembangan program pelatihan, untuk mencapai tujuan pelatihan; dan (c) evaluasi program pelatihan untuk menguji efektif atau tidaknya tujuan yang telah ditetapkan.
Kerangka berpikir yang mendasari penelitian ini adalah Peraturan Menteri Pendidikan Nasional nomor 13 tahun 2007 tentang Standar Kepala Sekolah. Salah satu kompetensi kepala sekolah yang menjadi fokus dalam penelitian ini adalah kompetensi supervisi, yang dapat ditingkatkan melalui pendidikan dan pelatihan calon kepala sekolah. Kerangka berpikir penelitian digambarkan pada Gambar 1 .

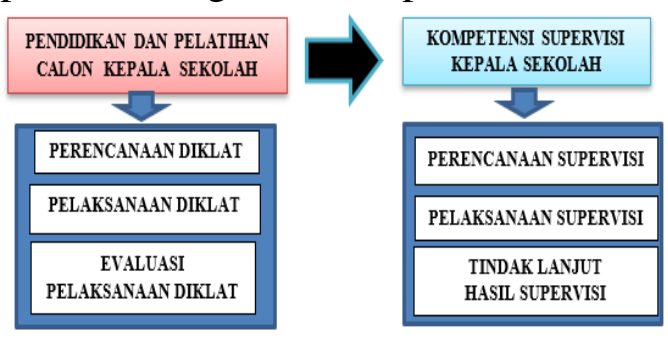

Gambar 1. Kerangka Berpikir

Adapun hipotesis dalam penelitian ini, dirumuskan sebagai berikut, "pendidikan dan pelatihan calon kepala sekolah dapat memberikan pengaruh yang signifikan terhadap peningkatan kompetensi supervisi kepala sekolah dasar di Kabupaten Bandung”.

\section{Metode Penelitian}

Metode penelitian yang digunakan adalah metode survai dengan pendekatan kuantitatif. Sampel penelitian sama dengan populasi sejumlah 72 orang. Instrumen pengumpulan data: (1) angket, (2) dokumentasi dan (3) tes. Angket terlebih dahulu diuji dengan uji validitas dan reliabel. Sedangkan untuk menguji hipotesis digunakan uji korelasi Product Moment, untuk mengetahui hubungan antara satu variabel dengan variabel lainnya, yang dinyatakan dengan 
besarnya koefisien korelasi keberartian (signifikansi), dengan rumus sebagai berikut (Sukmadinata, 2008:56)

$$
r_{y x}=\frac{n \sum X_{1} Y-\left(\sum X_{1}\right)\left(\sum Y\right)}{\sqrt{\left(n\left(\sum X i^{2}\right)-\left(\sum X_{1}\right)^{2}\right)\left(n \sum Y^{2}\right)-\left(\sum Y\right)^{2}}}
$$

Koefisien Korelasi Pearson (r) dengan ketentuan nilai $r$ tidak lebih dari harga $(-1 \leq \mathrm{r} \leq+1)$. Apabila nilai $\mathrm{r}=$ -1 artinya korelasi negatif sempurna, $\mathrm{r}=$ 0 artinya tidak ada korelasi, dan $\mathrm{r}=1$ berarti korelasinya sangat kuat. Sedangkan arti harga $r$ dapat dinterpretasikan berdasarkan pada tabel berikut

Interpretasi Koefisien Korelasi Nilai $r$

\begin{tabular}{|c|c|}
\hline $\begin{array}{c}\text { Interval } \\
\text { Koefisien }\end{array}$ & Tingkat Hubungan \\
\hline $0,80-1,000$ & Korelasi Sangat Kuat \\
$0,60-0,799$ & Korelasi Kuat \\
$0,40-0,599$ & Korelasi Cukup Kuat \\
$0,20-0,399$ & Korelasi Rendah \\
$0,00-0,199$ & Korelasi sangat Rendah \\
\hline
\end{tabular}

(Sugiyono, 2010:231)

Untuk menyatakan besar kecilnya sumbangan variabel $X$ terhadap variabel $\mathrm{Y}$, dapat ditentukan dengan rumus koefisien determinan :

$$
K D=r^{2} \times 100 \%
$$

KD = Nilai Koefiosien Determinan $\mathrm{r}$ = Nilai Koefisien Korelasi

\section{Hasil Penelitian dan Pembahasan}

Untuk variabel pendidikan dan pelatihan calon kepala sekolah yang diselenggarakan di LPMP Jawa Barat, diukur melalui indikator : 1) perencanaan, 2) pelaksanaan, dan 3) evaluasi. Hasil perhitungan skor ratarata, terdapat pada tabel 1 .

Tabel 1. Skor Rata-Rata Indikator Perencanaan Diklat

\begin{tabular}{|c|l|c|}
\hline No & \multicolumn{1}{|c|}{ Sub Indikator } & $\begin{array}{c}\text { Skor Rata- } \\
\text { Rata }\end{array}$ \\
\hline 1 & $\begin{array}{l}\text { Analisis Kebutuhan } \\
\text { diklat }\end{array}$ & 3,65 \\
\hline 2 & $\begin{array}{l}\text { Menyusun } \\
\text { Kurikulum Diklat }\end{array}$ & 3,72 \\
\hline 3 & Merumuskan Tujuan & 3,76 \\
\hline 4 & Menyusun Panduan & 3,78 \\
\hline 5 & $\begin{array}{l}\text { Menyiapkan } \\
\text { Fasilitas }\end{array}$ & 3,87 \\
\hline \multicolumn{2}{|c|}{ Skor Rata-Rata } & 3,75 \\
\hline
\end{tabular}

Sumber: Hasil Pengolahan data

Tabel 1 menunjukkan bahwa sub indikator analisis kebutuhan diklat menunjukan hasil analisis kebutuhan diklat telah digunakan untuk menyusun program diklat sesuai kebutuhan peserta, namun belum maksimal dapat menyelesaikan masalah tugas calon kepala sekolah. Sedangkan sub indikator menyiapkan fasilitas diklat menunjukan fasilitas diklat telah disiapkan sesuai dengan perencaanaan. Apabila dikonsultasikan dengan skala penafsiran skor rata-rata indikator perencanaan sebesar 3,75, maka angka tersebut pada rentang 3.40 - 4.19 atau pada kategori tinggi. Hal ini dapat disimpulkan bahwa perencanaan diklat calon kepala sekolah di LPMP Jawa Barat, umumnya berada pada kategori tinggi.

Tabel 2. Skor Rata-Rata Indikator Pelaksanaan Diklat

\begin{tabular}{|c|l|c|}
\hline No & \multicolumn{1}{|c|}{ Sub Indikator } & $\begin{array}{c}\text { Skor Rata- } \\
\text { Rata }\end{array}$ \\
\hline 1 & Materi Diklat & 3,62 \\
\hline 2 & $\begin{array}{l}\text { Metode } \\
\text { Pembelajaran }\end{array}$ & 3,68 \\
\hline
\end{tabular}




\begin{tabular}{|c|l|c|}
\hline 3 & $\begin{array}{l}\text { Media } \\
\text { Pembelajaran }\end{array}$ & 3,70 \\
\hline 4 & Fasilitator & 3,74 \\
\hline 5 & On The Job Training & 3,85 \\
\hline \multicolumn{2}{|r|}{ Skor Rata-Rata } & 3,72 \\
\hline
\end{tabular}

Sumber : Hasil Pengolahan data

Tabel 2 menunjukkan bahwa pelaksanaan diklat calon kepala sekolah di LPMP Jawa Barat, pada umumnya berada pada kategori tinggi.

Tabel 3. Skor Rata-Rata Indikator Evaluasi Diklat

\begin{tabular}{|c|l|c|}
\hline No & \multicolumn{1}{|c|}{ Sub Indikator } & $\begin{array}{c}\text { Skor Rata- } \\
\text { Rata }\end{array}$ \\
\hline 1 & Proses Pembelajaran & 3,83 \\
\hline 2 & Hasil Belajar & 3,90 \\
\hline 3 & Reaksi Peserta & 3,74 \\
\hline & Skor Rata-Rata & 3,82 \\
\hline
\end{tabular}

Sumber : Hasil Pengolahan data

Tabel 3 menunjukkan bahwa evaluasi diklat calon kepala sekolah di LPMP Jawa Barat, pada umumnya berada pada kategori tinggi. Oleh karena itu, secara keseluruhan dapat disimpulkan bahwa pendidikan dan pelatihan calon kepala sekolah dasar Kabupaten Bandung, yang diselenggarakan di LPMP Jawa Barat, berada pada kategori tinggi.

Untuk variabel supervisi akademik dalam penelitian ini diukur melalui indikator: 1) perencanaan supervisi akademik, 2) pelaksanaan supervisi akademik, dan 3) tindak lanjut supervisi. Hasil perhitungannya dapat dilihat pada tabel 4 sebagai berikut.

Tabel 4. Skor rata-rata Indikator Perencanaan Supervisi Akademik

\begin{tabular}{|c|l|c|}
\hline No & \multicolumn{1}{|c|}{ Sub Indikator } & $\begin{array}{c}\text { Skor Rata- } \\
\text { Rata }\end{array}$ \\
\hline 1 & $\begin{array}{l}\text { Identifikasi } \\
\text { masalah PBM Guru }\end{array}$ & 4,19 \\
\hline 2 & $\begin{array}{l}\text { Menyusun Program } \\
\text { Supak }\end{array}$ & 4,24 \\
\hline
\end{tabular}

\begin{tabular}{|c|c|c|}
\hline 3 & $\begin{array}{l}\text { Sosialisasi Program } \\
\text { Supak }\end{array}$ & 4,20 \\
\hline 4 & $\begin{array}{l}\text { Menyusun } \\
\text { Instrumen Supak }\end{array}$ & 4,11 \\
\hline & Skor Rata-Rata & 4,18 \\
\hline
\end{tabular}

Sumber : Hasil Pengolahan data

Tabel 4 menunjukkan bahwa perencanaan program supervisi akademik yang telah dilakukan kepala sekolah, pada umumnya berada pada kategori tinggi.

Tabel 5. Skor rata-Rata Indikator

Pelaksanaan Supervisi Akademik

\begin{tabular}{|c|l|c|}
\hline No & Sub Indikator & $\begin{array}{c}\text { Skor Rata- } \\
\text { Rata }\end{array}$ \\
\hline 1 & Pra Observasi & 4,13 \\
\hline 2 & Observasi kelas & 4,22 \\
\hline 3 & Pasca Observasi & 4,18 \\
\hline & Skor Rata-Rata & 4,17 \\
\hline
\end{tabular}

Tabel 5 menunjukkan bahwa pelaksanaan supervisi akademik yang telah dilakukan kepala sekolah, pada umumnya berada pada kategori tinggi.

Tabel 6. Skor rata-Rata Indikator

Tindak lanjut Supervisi Akademik

\begin{tabular}{|c|l|c|}
\hline No & \multicolumn{1}{|c|}{ Sub Indikator } & $\begin{array}{c}\text { Skor } \\
\text { Rata- } \\
\text { Rata }\end{array}$ \\
\hline 1 & Merefleksi & 4,14 \\
\hline 2 & Membuat Kesimpulan & 4,08 \\
\hline 3 & Menyusun Rekomendasi & 4,18 \\
\hline 4 & Mendokumentasikan & 4,25 \\
\hline \multicolumn{2}{|c|}{ Skor Rata-Rata } & 4,16 \\
\hline
\end{tabular}

Tabel 6 menunjukkan bahwa kepala sekolah telah membuat kesimpulan hasil supervisi yang telah dilakukan, namun belum sepenuhnya melibatkan guru dalam menganalisis hasil supervisi tersebut. Sedangkan sub indikator mendokumentasikan hasil supervisi akademik kepala sekolah telah 
menyusun laporan hasil kegiatan supervisi, dan digunakan sebagai acuan dalam penyusunan program supervisi selanjutnya. Hal ini dapat disimpulkan bahwa tindak lanjut hasil supervisi akademik yang telah dilakukan kepala sekolah, pada umumnya berada pada kategori tinggi. Oleh karena itu, secara keseluruhan dapat disimpulkan bahwa kepala sekolah dasar Kabupaten Bandun, telah melakukan tahap tindak lanjut hasil supervisi akademik, pada umumnya berada pada kategori tinggi

Efektivitas penyelenggaraan pendidikan dan pelatihan calon kepala sekolah dasar Kabupaten Bandung di LPMP Jawa Barat.

Hasil penelitian ini sesuai dengan pendapat Schuler, et al (1999:1-11) bahwa pendidikan dan pelatihan dirumuskan dalam 3 (tiga) tahapan, yaitu (a) assessment phase, tahap untuk menentukan kebutuhan apa saja yang direkomendasikan; (b) implementation phase, tahap implementasi pelatihan, berkaitan dengan isi dan proses pelatihan; dan (c) evaluation phase, tahap evaluasi untuk memastikan bahwa pelatihan yang dilaksanakan telah mencapai target yang ditentukan.

\section{Assessment phase yang} dilaksanakan di LPMP Jawa Barat, diawali dengan analisis kebutuhan pengembangan keprofesian (AKPK) bertujuan untuk menemukan adanya kesenjangan pengetahuan, keterampilan, dan sikap, yang dapat ditingkatkan melalui diklat. Sehingga hasil analisis tersebut digunakan untuk menyusun program diklat sesuai kebutuhan; menyusun kurikulum diklat disesuaikan dengan tujuan, materi, pengetahuan, sikap, dan keterampilan yang ingin dicapai; merumuskan tujuan diklat disesuaikan dengan kompetensi yang harus dimiliki kepala sekolah, dan menyiapkan fasilitas ruangan, administrasi peserta, dan kelengkapan penerangan lampu yang akan digunakan dalam pembelajaran. Dengan demikian perencanaan diklat di LPMP Jawa Barat, telah dilakukan sesuai dengan teori yang dikemukakan Schuler, et al, sehingga peserta diklat calon kepala sekolah yang akan menghadapi pekerjaan baru atau tugas-tugas baru, dapat berprestasi lebih baik dalam jabatan baruya.

Implementation phase, yang dilaksanakan di LPMP Jawa Barat, diawali dengan dinamika kelompok. Tujuannya untuk membina keakraban, dapat saling mengenal antara peserta diklat, antara peserta diklat dengan pelatih, dan mengkondisikan peserta diklat untuk siap melakukan kegiatan pelatihan, secara akrab dan menyenangkan. Hal ini sesuai pendapat Herman (2013:198-200) bahwa pelaksanaan pembelajaran dalam pelatihan, dapat membina keakraban, dapat saling mengenal antara peserta diklat, antara peserta diklat dengan pelatih. Upaya ini dilakukan untuk menghindari hambatan psikologis dalam kegiatan belajar, karena mereka tidak saling mengenal secara akrab antara satu dan lainnya. Pelaksanaan diklat calon kepala sekolah di LPMP Jawa Barat, diuraikan melalui penyampaian materi diklat dengan menggunakan metode pembelajaran yang bervariasi, dan media pembelajaran yang dapat memudahkan peserta dalam memahami materi yang disajikan fasilitator, dengan alur yang 
sistimatis, bahasa yang jelas dan fasih. Selain itu, pelaksanaan diklat dilakukan melalui on job training (OJT) yaitu melatih calon kepala sekolah yang sedang mengikuti diklat, untuk mempelajari materi pelatihan, dan mempraktekannya di lingkungan pekerjaannya sendiri, yang dibimbing oleh supervisor yang berpengalaman. Hal ini sesuai pendapat Hariandja (2005:186) bahwa OJT adalah pelatihan dalam bentuk penugasan pegawai yang ditempatkan dalam kondisi pekerjaan yang sebenarnya, dibawah bimbingan supervisor yang telah berpengalaman.

Evaluation phase, yang dilaksanakan di LPMP Jawa Barat, diawali dengan tes awal untuk mengetahui kemampuan awal peserta diklat sebelum mengikuti diklat, dan tes akhir setelah mengikuti diklat. Hal ini dilakukan untuk menguji efektivitas sebuah program pelatihan, sesuai dengan pendapat Dessler (2015:85). Evaluasi diklat calon kepala sekolah yang dilaksanakan LPMP Jawa Barat, diuraikan melalui evaluasi proses pembelajaran dilakukan fasilitator terhadap peserta diklat, baik penilaian pengetahuan, sikap, keaktifan dan keterampilan peserta, dengan menggunakan alat evaluasi sesuai tujuan yang ingin dicapai. Evaluasi hasil belajar dilakukan setelah mengikuti diklat, untuk mengukur pemahaman peserta diklat terhadap materi, dan presentasi hasil laporan OJT yang telah dilakukan. Selain itu evaluasi program diklat juga diuraikan melalui reaksi peserta, dalam mengembangkan cara kerja baru melalui sikap, pengetahuan, dan keterampilan yang diperoleh selama mengikuti diklat. Dari hasil perolehan nilai rata-rata pretes dan postes, menunjukkan adanya peningkatan nilai yang signifikan dari kegiatan diklat calon kepala sekolah yang dilaksanakan di LPMP Jawa Barat. Dengan demikian penyelenggaraan pendidikan dan pelatihan calon kepala sekolah dasar Kabupaten Bandung yang dilaksanakan di LPMP Jawa Barat, yang diukur melalui perencanaan diklat, pelaksanaan diklat dan evaluasi diklat, secara keseluruhan berada pada kategori tinggi dan efektif dapat mencapai target yang ditentukan. Namun demikian materi diklat yang digunakan perlu disusun lebih rinci, sistimatis dan lengkap, sehingga dapat mudah dipahami peserta diklat untuk menyelesaikan masalah tugas-tugas kepala sekolah.

Kompetensi supervisi kepala sekolah dasar Kabupaten Bandung setelah pendidikan dan pelatihan di LPMP Jawa Barat

Hasil penelitian ini sesuai dengan Permendiknas Nomor 13 tahun 2007, bahwa efektivitas dan kualitas pelayanan supervisi akademik yang dilaksanakan kepala sekolah, sebaiknya melalui prosedur yang tepat, yaitu (a) merencanakan program supervisi akademik, (b) melaksanakan supervisi akademik; dan (c) menindaklanjuti hasil supervisi untuk peningkatan profesionalisme guru.

Perencanaan program supervisi akademik yang dilakukan kepala sekolah dasar Kabupaten Bandung setelah mengikuti pendidikan dan pelatihan calon kepala sekolah di LPMP Jawa Barat, diawali dengan menyampaikan informasi kepada guru untuk mengidentifikasi permasalahan dalam proses pembelajaran, agar dapat 
membantu guru dalam menemukan masalah dan mencari solusi dari masalah pembelajaran yang ditemukan. Kemudian bersama guru merumuskan tujuan khusus supervisi akademik, membuat kisi-kisi insrumen dan membuat kesepakatan tentang instrumen supervisi akademik yang akan digunakan. Hal ini sesuai pendapat Pidarta (2009:99) bahwa perencanaan program supervisi adalah penyusunan dokumen perencanaan, dan pemantauan dalam mengembangkan kemampuan guru mengelola proses pembelajaran untuk mencapai tujuan.

Pelaksanaan supervisi akademik yang dilakukan kepala sekolah dasar Kabupaten Bandung pada pra observasi, yaitu melakukan pertemuan awal untuk menciptakan rasa nyaman terhadap guru yang akan disupervisi; meminta guru untuk menyiapkan rencana pembelajaran (RPP) yang akan digunakan, dan memvalidasi dokumen persiapan mengajar guru sebelum supervisi dilakukan. Kemudian kepala sekolah melakukan kunjungan kelas untuk mengamati langsung proses pembelajaran mulai dari kegiatan pendahuluan, proses sampai dengan kegiatan penutup; dan membuat catatan sesuai dengan instrumen yang sudah disepakati, untuk bahan mereview proses pembelajaran yang telah diobservasi. Hal ini sesuai pendapat Mulyasa (2013:252-256) bahwa pelaksanaan supervisi akademik terdapat 3 (tiga) tahap, yaitu (1) tahap pertemuan awal; (2) tahap observasi kelas; dan (3) tahap pasca observasi.

Tahap tindak lanjut hasil supervisi akademik yang dilakukan kepala sekolah dasar Kabupaten Bandung, yaitu memberikan masukan kepada guru terhadap proses pembelajaran, membuat kesimpulan dan menyusun rekomendasi perbaikan dari hasil supervisi yang telah dilakukan. Kemudian menyusun laporan hasil kegiatan supervisi, untuk digunakan sebagai bahan acuan penyusunan program supervisi selanjutnya, Hal ini sesuai dengan pendapat Donni (2014:117-120) bahwa cara-cara melaksanakan tindak lanjut hasil supervisi akademik, dapat dilakukan sebagai berikut: (1) mengkaji rangkuman hasil penilaian; (2) membuat rencana aksi sebagai tindak lanjut hasil supervisi yang telah dilakukan; dan (3) mengimplementasikan rencana aksi yang disusun, seperti sosialisasi, seminar, dan pelatihan. Oleh karena itu, tindak lanjut supervisi akademik sangat diperlukan untuk mengukur keberhasilan program supervisi, dan untuk mengetahui perkembangan proses mengajar guru yang dianggap belum maksimal.

Dengan demikian kompetensi supervisi kepala sekolah dasar Kabupaten Bandung, setelah mengikuti pendidikan dan pelatihan calon kepala sekolah di LPMP Jawa Barat, yang diuraikan melalui perencanaan program supervisi akademik, pelaksanaan supervisi akademik, dan tindak lanjut hasil supervisi akademik, secara keseluruhan berada pada kategori tinggi dan sudah dilakukan sesuai dengan prosedur yang ditetapkan. Namun perlu ditingkatkan kerjasama antara kepala sekolah dengan guru dalam penyusunan kisi-kisi instrumen supervisi yang akan 
digunakan, dan mengkaji dokumen persiapan mengajar guru sebelum supervisi dilakukan. Sehingga antara kepala sekolah dan guru tercipta suasana komunikasi yang harmonis, tidak menegangkan dan memberi kesempatan pada guru untuk memperbaiki kinerjanya.

Pengaruh pendidikan dan pelatihan calon kepala sekolah di LPMP Jawa Barat terhadap peningkatan kompetensi supervisi kepala sekolah dasar Kabupaten Bandung.

Berdasarkan hasil uji hipotesis bahwa pendidikan dan pelatihan calon kepala sekolah, dapat memberikan pengaruh yang signifikan terhadap peningkatan kompetensi supervisi kepala sekolah dasar di Kabupaten Bandung. Selain itu besarnya pengaruh pendidikan dan pelatihan calon kepala sekolah terhadap peningkatan kompetensi supervisi kepala sekolah diperoleh nilai sebesar 31,4\%, sedangkan sisanya sebesar $68,6 \%$ dapat dipengaruhi oleh faktor lain yang tidak diteliti dalam penelitian ini. Hal ini sesuai dengan pendapat Payong (2011:17) bahwa kompetensi adalah kemampuan yang dimiliki seseorang, akibat dari pendidikan maupun pelatihan, atau pengalaman belajar informal tertentu yang diperoleh, sehingga menyebabkan seseorang dapat melaksanakan tugas yang dipercayakan dengan penuh tanggung jawab dan profesional. Demikian pula dengan kompetensi supervisi kepala sekolah, dapat ditingkatkan melalui pendidikan dan pelatihan calon kepala sekolah. Kompetensi tersebut dapat diwujudkan dalam bentuk menyusun program supervisi akademik, melaksanakan supervisi akademik, dan menindaklanjuti hasil supervisi akademik untuk meningkatkan profesionalisme guru. Sehingga dengan meningkatnya kompetensi supervisi kepala sekolah, maka guru merasa lebih terbantu mengatasi permasalahan dalam melaksanakan proses pembelajaran.

\section{Kesimpulan}

Pertama, penyelenggaraan pendidikan dan pelatihan calon kepala sekolah dasar Kabupaten Bandung yang diselenggaran di LPMP Jawa Barat, yang diukur melalui perencanaan diklat, pelaksanaan diklat dan evaluasi diklat, secara keseluruhan berada pada kategori tinggi, dan efektif dapat mencapai target yang ditentukan. Karena program pendidikan dan pelatihan calon kepala sekolah di LPMP Jawa Barat, disusun berdasarkan hasil analisis kebutuhan pengembangan keprofesian (AKPK). Sehingga pelaksanaan diklat calon kepala sekolah, dapat berjalan dengan suasana pembelajaran yang kondusif, kreatif, inovatif dan menyenangkan. Selain itu hasil nilai rata-rata pretes dan postes peserta diklat calon kepala sekolah terdapat peningkatan nilai yang signifikan.

Kedua, kompetensi supervisi kepala sekolah dasar Kabupaten Bandung setelah pendidikan dan pelatihan calon kepala sekolah di LPMP Jawa Barat, yang diukur melalui perencanaan program supervisi akademik, pelaksanaan supervisi akademik, dan tindak lanjut hasil supervisi akademik, secara keseluruhan berada pada kategori tinggi. Karena melalui prosedur pelaksanaan supervisi yang dilakukan kepala sekolah dasar 
Kabupaten Bandung, dapat membantu guru dalam menghadapi kesulitan mengajar, sehingga diharapkan kualitas pembelajaran guru semakin meningkat, dan berdampak pada prestasi peserta didik.

Ketiga, pendidikan dan pelatihan calon kepala sekolah dapat memberikan pengaruh yang signifikan terhadap peningkatan kompetensi supervisi kepala sekolah dasar Kabupaten Bandung. Selain itu besarnya pengaruh pendidikan dan pelatihan calon kepala sekolah terhadap peningkatan kompetensi supervisi kepala sekolah.

\section{Rekomendasi}

Bagi instansi terkait, dalam hal ini Dinas Pendidikan baik di tingkat kota/kabupaten dan provinsi, dan Lembaga Pengembangan dan Pemberdayaan Kepala Sekolah (LPPKS), maupun Lembaga Penjaminan Mutu Pendidikan (LPMP) Jawa Barat, perlu meningkatkan dalam penyusunan program diklat berikutnya, secara khusus materi diklat yang digunakan agar disusun lebih rinci, sistimatis, dan lengkap agar dapat mudah dipahami oleh peserta diklat.

Bagi kepala sekolah dan guru, keberhasilan implementasi kompetensi supervisi perlu didukung oleh kesanggupan dan kesediaan untuk mengembangkan kisi-kisi instrumen supervisi akademik, seperti lembar observasi, angket, pedoman dan wawancara, secara terus menerus dan berkesinambungan, agar kompetensi supervisi yang dimiliki epala sekolah, dapat dilaksanakan sesuai dengan tugas dan fungsinya secara profesional.

\section{Daftar Pustaka}

Depdiknas, 2008. Metode dan Teknik Supervisi. Jakarta : Direktorat Tenaga Kependidikan, Dirjen Peningkatan Mutu Pendidikan dan Tenaga Kependidikan.

Dessler, Gary. 2015. Manajemen Sumber Daya Manusia. Jakarta : Salemba Empat.

Donni Juni dan Somad. 2014.

Manajemen Supervisi dan

Kepemimpinan Kepala Sekolah.

Bandung: Alfabeta

Hariandja, Marihot, T.E. 2005 Manajemen Sumber Daya Manusia. Jakarta : Grasindo

Hasibuan M., 2001. Manajemen Sumber Daya Manusia. Jakarta: Bumi Aksara.

Herman, Sofyandi, 2013. Manajemen Sumber Daya Manusia. Yogyakarta : Graha Ilmu

Kementerian Pendidikan dan Kebudayaan 2016. Panduan Diklat Calon Kepala Sekolah/Madrasah. Bandung : Lembaga Penjaminan Mutu Pendidikan Provinsi Jawa Barat

Mulyasa, E 2013. Menjadi Kepala Sekolah Profesional. Bandung: Remaja Rosdakarya

Notoatmodjo, Soekidjo. 2003.

Pengembangan Sumber Daya

Manusia. Jakarta : PT. Ranika Cipta. Payong, Marselus. 2011. Sertifikasi

Profesi Guru : Konsep Dasar, Problematika dan Implementasnya. Bandung : Alfabeta.

Pidarta, Made. 2009. Manajemen

Pendidikan Konstektual. Jakarta : Rineka Cipta 
Purwanto, M. Ngalim. 2008. Adminstrasi dan Supervisi Pendidikan. Bandung : Rosda Karya. Satori, Djam'an. 2004. Paradigma Baru Supervisi Pendidikan untuk Meningkatkan Mutu dalam Konteks Peranan Pengawas Sekolah dalam Otonomi Daerah. ASPI : Jabar.

Sergiovanni, T.J. 1987. Supervision of Teaching. Alexandria : Association for Supervision and Curriculum Development. Boston : Pearson.

Sugiyono. 2010. Metode Penelitian Pendidikan Pendekatan Kuantitatif, Kualitatif, dan R \& D. Bandung : Alfabeta.

Sukmadinata, Nana Syaodih. 2008.

Metode Penelitian Pendidikan. Bandung : Remaja Rosda Karya.
Sulistyani \& Rosidah. 2009. Manajemen Sumber Daya Manusia : Konsep, Teori, dan pengembangan dalam Konteks Organisasi Publik. Yogyakarta : Graha Ilmu.

Schuler, et.al. 1999. Pengembangan Sumber Daya Manusia Abad. 21. Terjemahan oleh Dwi Kartini Yahya. Jakarta : Rineka Cipta (https://edukasi.kompas.com/read/2012/ Kepala.Sekolah.Masih.Rendah, tanggal 24 Juli 2012).

(https://www.kompasiana.com/samsunis arman/wow-kompetensi-supervisi kepala-sekolah-rendah, tanggal 24 Jun 2015) 